\title{
AN EVALUATION OF CATALYTIC EMISSION CONTROLS TO PREVENT CARBON MONOXIDE POISONINGS FROM HOUSEBOAT GENERATOR EXHAUST
}

\author{
G. Scott Earnest, Ph.D, P.E., C.S.P. \\ Ronald M. Hall, M.S., C.I.H. \\ Alberto Garcia, M.S. \\ Robert McCleery, M.S.
}

REPORT DATE:

October 2006

\author{
REPORT NO.: \\ EPHB 171-38a
}

U.S. Department of Health and Human Services

Centers for Disease Control and Prevention

National Institute for Occupational Safety and Health

Division of Applied Research and Technology

4676 Columbia Parkway, MS - R5

Cincinnati, Ohio 45226 
Site Surveyed:

SIC Code:

Survey Dates:

Employer Representatives Contacted:

Employee Representatives Contacted:
Callville Bay Marina

Boulder City, Nevada

N/A

November 16-17, 2005

John Stenseth, General Manager

Fun Country Marine Industries

Forever Resorts, Inc.

None 


\section{DISCLAIMER}

Mention of any company or product does not constitute endorsement by the Centers for Disease Control and Prevention (CDC), National Institute for Occupational Safety and Health (NIOSH).

The findings and conclusions in this report are those of the authors and do not necessarily represent the views of the National Institute for Occupational Safety and Health. 


\section{EXECUTIVE SUMMARY}

Working under an interagency agreement with the United States Coast Guard, researchers from the National Institute for Occupational Safety and Health (NIOSH) evaluated carbon monoxide (CO) emissions, exposures, and controls from gasoline-powered generators on houseboats. This evaluation was part of a series of studies conducted by NIOSH investigators during the past several years to identify and recommend effective engineering controls to reduce the $\mathrm{CO}$ hazard and prevent $\mathrm{CO}$ poisonings on houseboats and other recreational marine vessels.

The performance of two (14-KW and 20-KW) Westerbeke, Safe-CO ${ }^{\mathrm{TM}}$ generators were tested after being used on rental houseboats for the boating season. Prior to performing the testing, a damaged oxygen sensor was replaced on the 14-KW generators and both old and new catalysts were evaluated. Each of the evaluated generators had between 1,000 and 3,000 hours of use and were equipped with catalytic converters and electronic fuel injection systems. A 12.5-KW Westerbeke generator was also tested that had been retrofitted with a Zenith electronic fuel injection (EFI) retrofit kit. Each of the engineering control devices were designed to improve generator performance and reduce $\mathrm{CO}$ emissions. The houseboat containing the 14- $\mathrm{KW}$ generator had been modified so that testing could be accomplished using either a side exhaust or stack exhaust configuration.

The performance of the two Westerbeke Safe-CO ${ }^{\mathrm{TM}}$ generators used for a season of boating was impressive; average $\mathrm{CO}$ concentrations at various locations on the boat was generally below 5 parts per million (ppm). Peak CO concentrations were all well below $20 \mathrm{ppm}$. Both older and brand new catalysts were evaluated. The new catalysts seemed to perform slightly better than the ones used for a season. CO concentrations were slightly lower under the no load conditions as compared to loaded. $\mathrm{CO}$ concentrations measured directly in the exhaust stack were approximately $200 \mathrm{ppm}$ for the fully warmed generator. That compares to CO concentrations NIOSH researchers measured which exceeded $10,000 \mathrm{ppm}$ on older Westerbeke generators without the Safe-CO ${ }^{\mathrm{TM}}$ control systems. When comparing side versus stack exhaust, the lower stern deck in the side exhaust configuration resulted in slightly higher concentrations.. Use of the Safe-CO ${ }^{\mathrm{TM}}$ generator resulted in low ambient $\mathrm{CO}$ concentrations for both side and stack exhaust configurations. Use of the vertical exhaust stack with the Safe-CO generator is recommended to ensure redundancy in the system in the event that the catalyst or oxygen sensor performance degrades with time. Development and commercialization of the Westerbeke Safe-CO ${ }^{\mathrm{TM}}$ system is a major advancement in control systems to ensure a safe environment around houseboats and other marine vessels.

The performance of the Westerbeke generator retrofitted with a Zenith EFI system was also good. CO concentrations measured on the boat were also typically below $5 \mathrm{ppm}$; however, the $\mathrm{CO}$ concentration measured directly in the exhaust was higher than the Safe-CO ${ }^{\mathrm{TM}}$ generators. The Zenith electronic fuel injection (EFI) system did not perform as well when the generator was under load, and $\mathrm{CO}$ concentrations measured directly in the exhaust were substantially higher. 


\section{BACKGROUND}

On November 16 and 17, 2005, National Institute for Occupational Safety and Health (NIOSH) researchers evaluated control of carbon monoxide (CO) emissions and exposures at Callville Bay Marina on Lake Mead, Nevada. The evaluation primarily involved the testing of Westerbeke Safe-CO ${ }^{\mathrm{TM}}$ generators installed on two houseboats. A $14 \mathrm{KW}$ Safe-CO ${ }^{\mathrm{TM}}$ generator, equipped with an exhaust system that could be routed either to a side exhaust or to a vertical stack exhaust, was tested on a Fun Country Marine VIP XT (16 X 59') houseboat. The second generator, a 20 KW Safe-CO ${ }^{\mathrm{TM}}$ Generator, was installed onto a Fun Country Marine Millennium (16' X 70') houseboat. Additionally, a $12.5 \mathrm{KW}$ Westerbeke generator, retrofitted with a Zenith Electronic Fuel Injection (EFI) kit and installed onto a Fun Country Marine Deluxe (14' X 59') houseboat was tested. All of the evaluations were conducted while the houseboats were docked at the marina.

Representatives from NIOSH, U.S. Coast Guard, U.S. National Park Service, Department of Interior, and Utah Parks and Recreation conducted initial investigations of carbon monoxide (CO)-related poisonings and deaths on houseboats at Lake Powell in September and October 2000. These investigations measured hazardous CO concentrations on houseboats at Lake Powell (McCammon and Radtke 2000). Some of the severely hazardous situations identified during the early studies included:

- The open space under the swim platform could be lethal under certain circumstances (i.e., generator/motor exhaust discharging into this area) on some houseboats.

- Some CO concentrations above and around the swim platform were at or above the immediately dangerous to life and health (IDLH) level [greater than 1,200 parts of CO per million parts of air (ppm)].

- Measurements of personal $\mathrm{CO}$ exposure during boat maintenance activities indicated that employees may be exposed to hazardous concentrations of $\mathrm{CO}$.

Epidemiological investigations have discovered that from 1990 to $2006,176 \mathrm{CO}$ poisoning cases occurred on Lake Powell near the border of Arizona and Utah. Eighty of the poisonings occurred inside the cabin of houseboats and all of these poisonings were attributable to generator exhaust. Thirty-six of the poisonings occurred outside the houseboats and 29 of these poisonings were attributable to the generator exhaust. Ten houseboat- related $\mathrm{CO}$ poisonings on Lake Powell resulted in death (National Case Listing 2006). Further investigations have identified nearly 607 $\mathrm{CO}$ poisonings related to recreational boats across the United States and that number continues to increase.

Engineering control studies began in February 2001 at Lake Powell and Somerset, Kentucky, (Dunn, Hall et al. 2001; Earnest, Dunn et al. 2001). Results of these studies demonstrated that an exhaust stack extending 9 feet above the houseboat's upper deck dramatically reduced the $\mathrm{CO}$ concentrations on and near the houseboat and provided a much safer environment. The U.S. Coast Guard, Office of Boating Safety, Recreational Boating Product Assurance Division convened a meeting on May 3, 2001, in Lexington, Kentucky. Houseboat manufacturers, marine 
product manufacturers, government representatives, and others interested in addressing the $\mathrm{CO}$ hazard attended this meeting. Following the meeting, NIOSH researchers were asked to evaluate the performance of a new prototype Emission Control Device (ECD) and an interlocking device and to conduct further evaluations of the dry stack. These evaluations were conducted in June 2001 at Callville Bay Marina, NV. The findings of these studies indicated that although the ECD, interlock, and dry stack each performed well, longer term testing of the ECD should be conducted (Dunn, Earnest et al. 2001; Earnest, Dunn et al. 2001). A second evaluation of the prototype ECD in October 2001 showed that performance of the prototype ECD had substantially degraded after thousands of hours of use; however, a new production ECD was developed that performed well. The prototype ECD consisted of a combination of stainless steel and cast iron while the production ECD consisted entirely of stainless steel to reduce corrosion with several engineering improvements. NIOSH researchers conducted a follow-up survey to evaluate the performance of the improved ECD after 2000+ hours of use. The results showed that the improved ECDs were somewhat effective at reducing $\mathrm{CO}$ concentrations; however, their performance had substantially degraded from when they were new (Earnest, Dunn et al. 2003).

The following study was primarily conducted to evaluate the performance of Westerbeke Safe$\mathrm{CO}^{\mathrm{TM}}$ generators that had been used for a season. These generators reduce carbon monoxide emissions using electronic fuel injection (EFI) to efficiently combust the gasoline. To reduce the remaining carbon monoxide emissions in the exhaust effluent, a catalytic converter was used. At the request of Fun Country Marine, a standard Westerbeke generator, retrofitted with a Zenith electronic fuel injection (EFI) system, was also tested.

\section{Symptoms and Exposure Limits}

$\mathrm{CO}$ is a lethal poison produced when fuels such as gasoline or propane are burned. It is one of many chemicals found in engine exhaust resulting from incomplete combustion. Because $\mathrm{CO}$ is a colorless, odorless, and tasteless gas, it can overcome the exposed person without warning. The initial symptoms of $\mathrm{CO}$ poisoning may include headache, dizziness, drowsiness, or nausea. Symptoms may advance to vomiting, loss of consciousness, and collapse if prolonged or high exposures are encountered. If the exposure level is high, loss of consciousness may occur without other symptoms. Coma or death may occur if high exposures continue (NIOSH 1972; NIOSH 1977; NIOSH 1979). The display of symptoms varies widely from individual to individual, and may occur sooner in susceptible individuals such as young or aged people, people with preexisting lung or heart disease, or those living at high altitudes (Proctor, Hughes et al. 1988; ACGIH 1996; NIOSH 2000).

Exposure to $\mathrm{CO}$ limits the ability of the blood to carry oxygen to the tissues by binding with the hemoglobin to form carboxyhemoglobin ( $\mathrm{COHb}$ ). Blood has an estimated 210-250 times greater affinity for $\mathrm{CO}$ than oxygen, thus the presence of $\mathrm{CO}$ in the blood can interfere with oxygen uptake and delivery to the body (Forbes, Sargent et al. 1945).

Although NIOSH typically focuses on occupational safety and health issues, the Institute is a public health agency, and cannot ignore the overlapping exposure concerns in this type of setting. NIOSH researchers have done a considerable amount of work related to controlling $\mathrm{CO}$ 
exposures in the past (Ehlers, McCammon et al. 1996; Earnest, Mickelsen et al. 1997; Kovein, Earnest et al. 1998). The general boating public may range from infant to aged, be in various states of health and susceptibility, and be functioning at a higher rate of metabolism because of increased physical activity.

\section{Exposure Criteria}

Occupational criteria for $\mathrm{CO}$ exposures are applicable to U.S. National Park Service (USNPS) and concessionaire employees shown to be at risk of boat-related $\mathrm{CO}$ poisoning. The occupational exposure limits noted below should not be used for interpreting general population exposures (such as visitors engaged in boating activities) because occupational standards do not provide the same degree of protection as they do for the healthy worker population. The effects of $\mathrm{CO}$ are more pronounced and the time of onset of effects is shorter if the person is physically active, very young, very old, or has preexisting health conditions such as lung or heart disease. Persons at extremes of age and persons with underlying health conditions may have marked symptoms and may suffer serious complications at lower levels of carboxyhemoglobin.

Standards relevant to the general population consider these factors, and are listed following the occupational criteria.

The NIOSH Recommended Exposure Limit (REL) for occupational exposures to $\mathrm{CO}$ gas in air is 35 parts per million (ppm) for full shift time-weighted average (TWA) exposure, and a ceiling limit of $200 \mathrm{ppm}$, which should never be exceeded (CDC 1988; CFR 1997). The NIOSH REL of $35 \mathrm{ppm}$ is designed to protect workers from health effects associated with $\mathrm{COHb}$ levels in excess of $5 \%$ (Kales 1993). NIOSH has established the immediately dangerous to life and health (IDLH) value for CO of 1,200 ppm (NIOSH 2000). The American Conference of Governmental Industrial Hygienists (ACGIH) recommends an 8-hour TWA threshold limit value (TLV) for occupational exposure of $25 \mathrm{ppm}$ (ACGIH 1996) and discourages exposures above $125 \mathrm{ppm}$ for more than 30 minutes during a workday. The Occupational Safety and Health Administration (OSHA) permissible exposure limit (PEL) for CO is $50 \mathrm{ppm}$ for an 8-hour TWA exposure (CFR 1997).

\section{Health Criteria Relevant to the General Public}

The U.S. Environmental Protection Agency (EPA) has promulgated a National Ambient Air Quality Standard (NAAQS) for CO. This standard requires that ambient air contain no more than $9 \mathrm{ppm}$ CO for an 8-hour TWA, and $35 \mathrm{ppm}$ for a 1-hour average (EPA 1991). The NAAQS for $\mathrm{CO}$ was established to protect the most sensitive members of the general population.

The World Health Organization (WHO) has recommended guideline values and periods of timeweighted average exposures related to CO exposure in the general population [WHO 1999]. 
WHO guidelines are intended to ensure that $\mathrm{COHb}$ levels not exceed $2.5 \%$ when a normal subject engages in light or moderate exercise. Those guidelines are:

$100 \mathrm{mg} / \mathrm{m}^{3}(87 \mathrm{ppm})$ for 15 minutes

$60 \mathrm{mg} / \mathrm{m}^{3}(52 \mathrm{ppm})$ for 30 minutes

$30 \mathrm{mg} / \mathrm{m}^{3}$ (26 ppm) for 1 hour

$10 \mathrm{mg} / \mathrm{m}^{3}(9 \mathrm{ppm})$ for 8 hours 


\section{METHODS}

Carbon monoxide and other environmental measurements were collected on three houseboats built by Fun Country Marine Industries, Inc. (Muncie, IN). Testing involved the evaluation of Westerbeke Safe-CO ${ }^{\mathrm{TM}}$ generators installed on two houseboats. A $14 \mathrm{KW}$ Safe-CO ${ }^{\mathrm{TM}}$ Generator, equipped with an exhaust system that could be routed either to a side exhaust or to a vertical stack exhaust, was tested on a Fun Country Marine VIP XT (16' X 59') houseboat. The second generator, a $20 \mathrm{KW}$ Safe-CO ${ }^{\mathrm{TM}}$ generator, was installed onto a Fun Country Marine Millennium (16' X 70') houseboat. Additionally, a 12.5KW Westerbeke generator, retrofitted with a Zenith Electronic Fuel Injection (EFI) kit and installed onto a Fun Country Marine Deluxe (14' X 59') houseboat was tested. All of the evaluations were conducted while the houseboats were docked at the marina.

The generators on the houseboats provided electrical power for air conditioning, kitchen appliances, entertainment systems, navigation, and communications equipment. The engine compartment beneath the stern deck near the drive engines housed the generators. The generators are similar in size to engines used on small automobiles. Nearly $75 \%$ of houseboats in the U.S. use Westerbeke generators (Westerbeke 2001). When used on houseboats, the hot exhaust gases from the generators are injected with water near the end of the exhaust manifold in a process commonly called water-jacketing. Water-jacketing is used for exhaust cooling and noise reduction. Because the generator is situated below the waterline, the water-jacketed exhaust passes through a lift muffler that further reduces noise and forces the exhaust gases and water up and out through a hole beneath the swim platform.

\section{Description of the Evaluated Engineering Controls}

Two of the houseboats tested had a continuous, vertical exhaust stack fitted to the generator set. For the purposes of comparing the exhaust location on the results, a Fun Country Marine VIP XT (16' X 59') houseboat was configured to allow the exhaust emissions to be rapidly changed from a side to stack exhaust configuration. The Fun Country Marine Deluxe (14' X 59') houseboat also had a stack, but could not be easily changed to side exhaust for testing. Finally, the Fun Country Marine Millennium (16' X 70') houseboat did not have a stack and was discharging the Westerbeke Safe-CO ${ }^{\mathrm{TM}}$ generator exhaust at the side of the boat near the water line. The exhaust stacks on the two Fun Country houseboats were designed to comply with the revised American Boat and Yacht Council (ABYC) Standard P-1 for recreational boat exhaust. A 2-inch nominal, schedule 40 aluminum pipe, having an approximately 2.5 -inch outside diameter and 2.0 -inch inside diameter was used as the stack.

The focus of this study was to evaluate the performance of Westerbeke Safe-CO ${ }^{\mathrm{TM}}$ Generators specifically designed to produce low CO emissions. A $14 \mathrm{KW}$ Safe-CO ${ }^{\mathrm{TM}}$ Westerbeke generator was tested on a Fun Country Marine VIP XT (16' X 59') houseboat. The generator logged 2,300 hours of use before the evaluation. Additionally, a $20 \mathrm{KW}$ Safe-CO ${ }^{\mathrm{TM}}$ Westerbeke generator was tested on a Fun Country Marine Millennium (16' X 70') houseboat. This generator logged 1,254 hours of use before the evaluation. Given the proprietary nature of this technology, little information could be obtained regarding the specific control technologies used to reduce the 
carbon monoxide emissions. However, an electronic fuel injection system was employed to efficiently combust the gasoline to help reduce exhaust emissions, including carbon monoxide.

Secondly, a catalytic air pollution control device was designed to optimize the chemical oxidation of carbon monoxide in the generator exhaust emissions. To prevent excessive heat buildup in the catalyst, the device was water-jacketed. The manufacturer recommends replacing the catalyst after 2000 hours of use. The manufacturer also recommends that carbon monoxide emissions be spot checked at 1000 hours of use. Stainless steel was selected as the catalyst housing to inhibit corrosion from the harsh marine environment. The catalytic ingredients used in the catalyst were not revealed by the manufacturer, but normally are composed of metal or metal oxides (e.g., $\mathrm{Pt}, \mathrm{Pd}, \mathrm{Rh}, \mathrm{V}_{2} \mathrm{O}_{5}$ ). These metals are normally dispersed onto a high surface area porous structure (e.g., $\mathrm{Al}_{2} \mathrm{O}_{3}, \mathrm{SiO}_{2}$ ) located within the catalyst. Exhaust gases adsorbed onto the surface undergo catalytic reactions. A catalyst increases the rate of a chemical reaction without undergoing a permanent change itself (Heck, R.M., Farrauto, R.J., 1995).

At the request of Fun Country Marine, an older model $12.5 \mathrm{KW}$ Westerbeke generator was also evaluated that had been retrofitted with an aftermarket electronic fuel injection kit. The aftermarket kit, a Zenith Electronic Fuel Injection Kit, contained a throttle body injection unit, an engine management module, and a fuel pump/vapor separator. The retrofit involved the removal of the manufacturer's carburetor, mechanical governor, and fuel pump. The generator was placed in a Fun Country Marine Deluxe (14' X 59') houseboat. Since the retrofit, this generator logged 2,991 hours of use.

\section{Description of the Evaluation Equipment}

A Ferret Instruments (Cheboygan, MI) Gaslink LT Five Gas Emissions Analyzer characterized emissions from the generator and drive engines. This analyzer measures carbon monoxide (CO), carbon dioxide $\left(\mathrm{CO}_{2}\right)$, hydrocarbons, oxygen, and nitrogen oxides $\left(\mathrm{NO}_{\mathrm{x}}\right)$. All measurements are expressed as percentages except hydrocarbons and $\mathrm{NO}_{\mathrm{x}}$, which is ppm. [One percent of contaminant is equivalent to $10,000 \mathrm{ppm}$.]

ToxiUltra Atmospheric Monitors (Biometrics, Inc.) with CO sensors measured CO concentrations at various locations on the houseboat. ToxiUltra $\mathrm{CO}$ monitors were calibrated before and after use according to the manufacturer's recommendations. These monitors are direct-reading instruments with data logging capabilities. The instruments were operated in the passive diffusion mode, with a 30 second sampling interval. The instruments have a nominal range from $0 \mathrm{ppm}$ to $999 \mathrm{ppm}$. Accuracy is $+/-1 \mathrm{ppm}$ or 5 percent of the reading (whichever is greatest).

$\mathrm{CO}$ concentrations were also measured with detector tubes [Draeger A.G. (Lubeck, Germany) $\mathrm{CO}, \mathrm{CH} 29901$ ranges $2-60 \mathrm{ppm}, 10-3000 \mathrm{ppm}$, and 3000-70,000 ppm] in the areas adjacent the side exhaust (i.e., $\sim 24$ " above the exhaust) when testing a houseboat in this configuration mode and directly in the generator exhaust when testing a houseboat in a top exhaust configuration. The detector tubes are used by drawing air through the tube with a bellows type pump. The 
resulting length of the stain in the tube (produced by a chemical reaction with the sorbent) is proportional to the concentration of the air contaminant.

Grab samples were collected using Mine Safety and Health Administration (MSHA) 50mL glass evacuated containers. These samples were collected by snapping open the top of the glass container and allowing the air to enter. The containers were sealed with wax impregnated MSHA caps. DataChem Laboratories, Inc. in Salt Lake City, Utah analyzed the samples for CO using a Varian 3800 gas chromatograph equipped with a methanizer and thermal conductivity, flame ionization and electron capture detectors.

Wind velocity measurements were gathered each minute during the air sampling using an omnidirectional (Gill Instruments Ltd., Hampshire, U.K.) ultrasonic anemometer. This instrument uses a basic time-of-flight operating principle that depends upon the dimensions and geometry of an array of transducers. Transducer pairs alternately transmit and receive pulses of high frequency ultrasound. The time-of-flight of the ultrasonic waves are measured, recorded, and is used to calculate wind velocities in the $\mathrm{X}$ - and $\mathrm{Y}$-axes. This instrument is capable of measuring wind velocities of up to 45 meters per second $(\mathrm{m} / \mathrm{sec})$ and take 100 measurements per second. Temperature and relative humidity measurements were collected using a TSI Velocicalc Plus (Model 8360, St. Paul, MN).

\section{Description of Procedures}

The evaluation was performed over a 2-day period using a variety of operating conditions and generator exhaust configurations. In each case, the houseboats were tested while moored at the marina. Details concerning the testing of each houseboat are summarized below:

- Fun Country Marine VIP XT (16' X 59') with a $14 \mathrm{KW}$ Safe-CO ${ }^{\text {TM }}$ Westerbeke Generator. In this houseboat, the generator emissions could be configured to exhaust through either a side or vertical exhaust stack. Additionally, testing was accomplished under no-load and $1 / 2$ load conditions. Half load conditions were accomplished by running the air conditioning unit. In each case, the generator operated under $1 / 2$ load conditions when sufficiently warm $(30+$ minutes of operation under no-load generator operation).

- Fun Country Marine Millenium (16' X 70') with a $20 \mathrm{KW}$ Safe-CO ${ }^{\text {TM }}$ Westerbeke Generator. In this houseboat, the generator emissions were configured to only exhaust from a vertical exhaust stack. Additionally, testing was accomplished under no-load and $1 / 2$ load conditions. Half load conditions were accomplished by running the air conditioning unit. In each case, the generator operated under $1 / 2$ load conditions when sufficiently warm ( $30+$ minutes of operation under no-load generator operation).

- Fun Country Marine Deluxe (14' X 59') with a $12.5 \mathrm{KW}$ Westerbeke Generator retrofitted with a Zenith Electronic Fuel Injection (EFI) Kit. In this houseboat, the generator emissions were configured to only exhaust from a vertical exhaust stack. Additionally, testing was accomplished under no-load and $1 / 2$ load conditions. Half load 
conditions were accomplished by running the air conditioning unit. In each case, the generator operated under $1 / 2$ load conditions when sufficiently warm ( $30+$ minutes of operation under no-load generator operation).

Figure 1 presents the sampling locations, designated with numbers, for the ToxiUltra real-time $\mathrm{CO}$ monitors on the lower and upper decks of the houseboats. The monitors were placed at nine sample locations on the upper and lower decks of the houseboat to provide representative samples of occupied areas. Grab samples using the Ferret Instrument Gas Analyzer, Draeger detector tubes, and evacuated containers were also taken near (i.e., side exhaust configuration) or within the generator exhausts (top exhaust configuration). Additionally, an ultrasonic anemometer collected wind direction and speed measurements during the testing while a TSI Velocicalc Plus monitored temperature and relative humidity measurements. 


\section{RESULTS}

\section{Results of Air Sampling with ToxiUltra CO Monitors}

Real-time $\mathrm{CO}$ monitoring was conducted at numerous locations on the evaluated houseboats (Figure 1). Tables I through VII present the summary statistics for the data. Details concerning the sample results for each houseboat are summarized below:

- Fun Country Marine VIP XT (16' X 59') with a 14-KW Safe-CO ${ }^{\text {TM }}$ Westerbeke Generator. Tables I through IV present the results for this generator. Tables I and II contain data for the old catalyst and Tables III and IV contain data for the new catalyst. Tables III and IV contain data for two distinct runs one with side exhaust and the other with stack exhaust. The $\mathrm{CO}$ concentrations on both the lower and upper decks were extremely low for all conditions tested (average $\mathrm{CO}$ concentrations were typically below $3 \mathrm{ppm}$ even at the stern of the boat). Peak CO concentrations were typically below 10 ppm for all conditions. When comparing the real time results for the side exhaust versus the stack exhaust there were only minor differences. For example, average $\mathrm{CO}$ concentration differences measured at the same location were generally less than $1 \mathrm{ppm}$. The lower deck showed slightly higher concentration when using the side exhaust configuration compared to stack exhaust. There also did not appear to be major differences when the generator was under load compared to idling (again typically less than $1 \mathrm{ppm}$ difference).

- Fun Country Marine Deluxe (14' X 59') with a 12.5-KW Westerbeke Generator retrofitted with a Zenith Electronic Fuel Injection (EFI) Kit. Table V shows the data for this generator. Average CO concentrations were comparable to the previous tests using vertical exhaust stacks. The highest peak concentration measured during this test was $14 \mathrm{ppm}$ (sample location 5). A generator load increase to one-half of capacity appeared to influence $\mathrm{CO}$ concentrations measured in the environment. Measured peak $\mathrm{CO}$ concentrations in some cases increased 5 to 10 fold when running this generator under no load compared to half load. For example, on the lower stern deck (sample \# 5), the peak $\mathrm{CO}$ concentration went from $2 \mathrm{ppm}$ under no load to $14 \mathrm{ppm}$ under half-load. Additional information about this generator performance is shown in Table V.

- Fun Country Marine Millennium (16' X 70') with a 20-KW Safe-CO ${ }^{\mathrm{TM}}$ Westerbeke Generator. The results for this larger Safe-CO ${ }^{\mathrm{TM}}$ generator were also extremely low as shown in Tables VI and VII. Table VI contains data for the old catalyst and Table VII contains data for the new catalyst. The highest peak concentration measured during this test was $6 \mathrm{ppm}$ (sample location 1). Most peak concentrations were less than $2 \mathrm{ppm}$ and many average concentrations were less than $1 \mathrm{ppm}$. Unlike the Zenith EFI system, increasing the generator load to one-half of capacity did not significantly increase $\mathrm{CO}$ emissions (engine was warmed). CO concentrations measured when using the new catalyst appeared to be slightly lower than the old catalyst in this generator. 


\section{Gas Emissions Analyzer, Detector Tubes, and Evacuated Container Results}

Gas emissions analyzers, detector tubes, and glass-evacuated containers were used to characterize $\mathrm{CO}$ concentrations in and near the exhaust stack. This equipment was utilized because it is capable of reading higher $\mathrm{CO}$ concentrations than the ToxiUltra $\mathrm{CO}$ monitors which have an upper limit of approximately $1,000 \mathrm{ppm}$. Tables VIII (detector tubes) and IX (evacuated containers) summarize the grab sample data and is discussed for each houseboat in the following:

- Fun Country Marine VIP XT (16' X 59') with a 14 KW Safe-CO ${ }^{\text {TM }}$ Westerbeke Generator. CO concentrations for the side exhaust configuration for both the no-load and $1 / 2$ load conditions were often not detected or very low. Measurements taken within the vertical exhaust stack exhaust plume reached an instantaneous level of approximately $81,000 \mathrm{ppm}$ during the cold start of the generator and decreased to very low values approximately 5 minutes later. When comparing the fully warmed $1 / 2$ load condition to the no load condition, there did not appear to be a significant difference in $\mathrm{CO}$ measurements - both conditions were very low. CO measurements ranged from 1 to 39 ppm throughout the day. An instantaneous level of $77 \mathrm{ppm}$ was observed when the generator was under load.

- Fun Country Marine Deluxe (14'X 59') with a 12.5 KW Westerbeke Generator retrofitted with a Zenith Electronic Fuel Injection Kit. All CO concentrations reported were measured within the vertical exhaust stack. CO concentrations increased rapidly after the cold start, reaching four percent $(40,000 \mathrm{ppm}) \mathrm{CO}$. Within several minutes, the CO measurements appeared to stabilize to below $800 \mathrm{ppm}$. CO concentrations were significantly higher when the generator was under half-load compared with no load.

- Fun Country Marine Millennium (16' X 70') with a $20 \mathrm{KW}$ Safe-CO ${ }^{\mathrm{TM}}$ Westerbeke Generator. CO concentrations measured within the vertical exhaust plume increased rapidly after a cold start, at one time approaching twelve percent $(119,000 \mathrm{ppm}) \mathrm{CO}$. Within several minutes, the $\mathrm{CO}$ measurements stabilized at approximately $100 \mathrm{ppm}$. After the generator had been run for several minutes, $\mathrm{CO}$ concentrations measured in the stack were quite low (typically less than a few hundred ppm).

\section{Weather Measurements}

During the survey, an ultrasonic anemometer gathered wind velocity measurements. All of the testing occurred at the marina where the houseboats were oriented at a constant bearing of approximately 300 (roughly northwest). Average ambient temperatures during the two days of data collection ranged from: $63^{\circ} \mathrm{F}$ to $75^{\circ} \mathrm{F}$. The predominant wind direction was roughly southwest (bearing of 202). Wind speeds were light and variable. The highest average wind speed was $1.6 \mathrm{~m} / \mathrm{s}$ (3.6 miles per hour) measured on the afternoon of November $16^{\text {th }}$. These relatively low wind speeds would also tend to create conditions considered "worst case" for houseboat occupants. 


\section{DISCUSSION AND CONCLUSIONS}

Retrofitting engineering emission control systems to the generators can greatly reduce the $\mathrm{CO}$ poisoning hazard to swimmers and occupants on houseboats that have gasoline-powered generators. Previous studies have shown that an exhaust stack (that releases the $\mathrm{CO}$ and other emission components high above the upper deck of the houseboat) allows the contaminants to diffuse and dissipate into the atmosphere away from boat occupants (Dunn, Hall et al. 2001; Earnest, Dunn et al. 2001). This study specifically evaluated the performance of two Westerbeke Safe-CO ${ }^{\mathrm{TM}}$ generators designed to reduce $\mathrm{CO}$ emissions and protect boat occupants. This was the second evaluation of these generators by NIOSH, and the first such evaluation after their operation for significant hours (several thousand hours). Previously, NIOSH researchers evaluated these three houseboats to determine the performance of the generators with just a few hours of operation (100-190 hours). Tests were conducted to determine the performance of the Safe- $\mathrm{CO}^{\mathrm{TM}}$ generators based upon the configuration (side exhaust versus top stack exhaust and to allow sampling directly in the exhaust) as well as the electrical load (no load versus $1 / 2$ load). Results of the current evaluation were excellent. Additional testing was performed on an older, Westerbeke generator that had been retrofitted with an aftermarket Zenith EFI system

\section{Westerbeke Safe-CO ${ }^{\mathrm{TM}}$ Generator Performance}

Results for both of the Safe-CO ${ }^{\mathrm{TM}}$ generators tested were outstanding and supported the results from the previous survey conducted in March 2005. CO concentrations in the generator exhaust and in the ambient environment on the houseboats were extremely low. The generator performed as designed and kept $\mathrm{CO}$ concentrations at very safe levels. On both of the Safe-CO ${ }^{\mathrm{TM}}$ generators an increase in electrical load on the generators equipped with the catalyst (1/2 load) resulted in little difference in $\mathrm{CO}$ emissions compared to no load conditions. The generators tested had approximately 1300 to 2300 hours of operation. As expected, the cold start condition resulted in very brief, high level transient $\mathrm{CO}$ concentrations. However, as the catalytic control device warmed to an optimal efficiency, the stack emissions dramatically reduced to less than a few hundred ppm (1000 fold decrease) after approximately a few minutes.

The current study demonstrated that the Westerbeke Safe-CO ${ }^{\mathrm{TM}}$ generator performed well over time, with no signs of significant degradation or change of performance throughout the life of the catalytic converter. Manufacturer recommends changing the catalytic plug after 2000 hours of operation. This evaluation have proved that 2000 hours is a safe limit for scheduling maintenance, keeping in mind that manufacturers recommend to spot check concentrations after 1,000 hours of operation.

\section{Exhaust Configuration}

Data was gathered from a Fun Country Marine VIP XT (16' X 59') houseboat using a $14 \mathrm{KW}$ Low CO Westerbeke Generator that could be configured to exhaust the generator emission from a side exhaust or top stack exhaust configuration. The results of air sampling with ToxiUltra CO Monitors located on the lower and upper decks demonstrated low $\mathrm{CO}$ emissions for both configurations. When comparing the real-time results for the side versus vertical stack exhaust, there were slightly higher concentrations on the lower stern deck. Use of the Safe-CO ${ }^{\mathrm{TM}}$ 
generator resulted in very low $\mathrm{CO}$ concentrations for both configurations. It is important that the boater/owner/operator follow all of the maintenance recommendations provided by the manufacturer. Some of those recommendations include periodically changing out the oxygen sensor in the generator and the catalyst may be changed. Use of the vertical exhaust with these houseboats generators is a good redundant safety measure.

\section{Westerbeke Generator Retrofitted with a Zenith EFI}

$\mathrm{CO}$ results for the older $12.5 \mathrm{KW}$ Westerbeke generator, retrofitted with an aftermarket EFI, were also good. The greatest difference in performance between this system and the Westerbeke system occurred while the generator was under load. CO concentrations in the exhaust increased significantly on this system while the generator was operating under load. The cold start condition also resulted in a transient increase in stack emissions that were greater than 4 percent CO. Considering that a catalytic air pollution control device was not added to this generator set, the steady state $\mathrm{CO}$ concentrations were generally quite low. 


\section{RECOMMENDATIONS}

The following recommendations are provided to reduce $\mathrm{CO}$ concentrations near houseboats and provide a safer and healthier environment.

1) All manufacturers/owners/users of U.S. houseboats with gasoline-powered generators should be aware of and concerned about the location of the exhaust terminus. Based on data from numerous NIOSH field surveys, we recommend evaluation of houseboats with gasoline-powered generators for potential $\mathrm{CO}$ exposures and poisonings and retrofitted with effective control systems to reduce the potential hazard of $\mathrm{CO}$ poisoning.

2) The performance of the Westerbeke Safe- $\mathrm{CO}^{\mathrm{TM}}$ generators was impressive with exhaust stack $\mathrm{CO}$ emissions of approximately $200 \mathrm{ppm}$ and below for a fully warmed generator. Due to diffusion, these emissions were significantly reduced such that highest average real-time $\mathrm{CO}$ reading, obtained from the monitors placed throughout the houseboat, were frequently single digit and all below $20 \mathrm{ppm}$ (side exhaust configuration). In order to ensure that the systems operate effectively, houseboat owners and operators should ensure that they follow all manufacturers' recommendations with regard to routine maintenance schedules.

3) The performance of the Westerbeke generator retrofitted with a Zenith EFI was also good with a stack $\mathrm{CO}$ emission below $800 \mathrm{ppm}$ for the a fully warmed generator. Diffusion significantly reduced these emissions such that the highest average real-time $\mathrm{CO}$ reading obtained from the monitors placed throughout the houseboat, was $13 \mathrm{ppm}$ (side exhaust configuration). Because of its design, this system was not as effective at lowering $\mathrm{CO}$ concentrations when the generator was operating under a load.

4) The vertical exhaust stack on Fun Country Marine houseboats performed well during the current study. Based upon the results of this and previous NIOSH evaluations of the vertical exhaust stack, NIOSH research indicates that the vertical stack, when properly designed and installed, is a viable, low-cost, engineering control that will dramatically improve the safety of houseboat users. The vertical exhaust stack should be retrofitted to existing and older generators as well as onto the new Safe-CO ${ }^{\mathrm{TM}}$ generators for system redundancy. 


\section{REFERENCES}

ABYC (2002) Standard P-1 Installation of Exhaust Systems for Propulsion and Auxiliary Engines. Edgewater, MD, American Boat and Yacht Council.

ACGIH (1996). Documentation of Threshold Limit Values and Biological Exposure Indices. Cincinnati, $\mathrm{OH}$, American Conference of Governmental Industrial Hygienists.

CARB (1998). Evaluation of Unlimited Technologies International, Inc.'s Series SA090 New Aftermarket Three-way Catalytic Converter for Exemption From the Prohibitions in Vehicle Code Section 27156, and Title 13 California Code of Regulations Section 2222(h). El Monte, CA, State of California Air Resources Board: 6.

CDC (1988). MMWR 37, supp (S-7) NIOSH Recommendations for Occupational Safety and Health Standards. Atlanta, GA, Department of Health and Human Services, Public Health Service, Centers for Disease Control and Prevention, National Institute for Occupational Safety and Health.

CFR (1997). 29 CFR 1910.1000, Chapter XVII - Occupational Safety and Health Administration. Code of Federal Regulations, Table Z-1, Limits for Air Contaminants. Washington, DC: U.S. Federal Register.

CFR (1997). 29 CFR 1910.1000, Code of Federal Regulations. Washington, DC: U.S., Government Printing Office, Federal Register.

Dunn, K.H.; Earnest, G.S.; McCleery, R.; Hall, R.M.; McCammon, J.B.; Jones. A.L. [2001]: Comparison of a Dry Stack with Existing Generator Exhaust Systems for Prevention of Carbon Monoxide Poisonings on Houseboats. Cincinnati, OH: U.S. Department of Health and Human Services, Public Health Service, Centers for Disease Control and Prevention, National Institute for Occupational Safety and Health, DHHS (NIOSH) Publication No. ECTB 171-28a.

Dunn, K.H.; Hall, R.M.; McCammon, J.B.; Earnest, G.S. [2001]: An Evaluation of an Engineering Control to Prevent Carbon Monoxide Poisonings of Individuals On Houseboats at Sumerset Custom Houseboats, Somerset, KY. Cincinnati, OH: U.S. Department of Health and Human Services, Public Health Service, Centers for Disease Control and Prevention, National Institute for Occupational Safety and Health, DHHS (NIOSH) Publication No. ECTB 171-26a.

Earnest, G. S., R. L. Mickelsen, et al. (1997). Carbon Monoxide Poisonings from Small, Gasoline-Powered, Internal Combustion Engines: Just What Is a "Well-Ventilated Area"?" Am. Ind. Hyg. Assoc. J. 58(11): 787-791. 
Earnest, G.S.; Dunn, K.H. Hall, R.M.; McCleery, R.; McCammon, J.B. [2001]: An Evaluation of an Engineering Control to Prevent Carbon Monoxide Poisonings of Individuals On and Around Houseboats. Cincinnati, OH: U.S. Department of Health and Human Services, Public Health Service, Centers for Disease Control and Prevention, National Institute for Occupational Safety and Health, DHHS (NIOSH) Publication No. ECTB 171-25a.

Earnest, G.S.; Dunn, K.H.; Hall, R.M.; McCleery, R.; McCammon, J.B. [2001]: An Evaluation of an Emission Control Device, Exhaust Stack, and Interlock to Prevent Carbon Monoxide Poisonings of Individuals On Houseboats. Cincinnati, OH: U.S. Department of Health and Human Services, Public Health Service, Centers for Disease Control and Prevention, National Institute for Occupational Safety and Health, DHHS (NIOSH) Publication No. ECTB 171-27a.

Earnest, G. S., K. H. Dunn, et al. (2001). An Evaluation of an Emission Control Device, Exhaust Stack, and Interlock to Prevent Carbon Monoxide Poisonings of Individuals on Houseboats. Cincinnati, Oh, U.S. Dept. of Health and Human Services, Public Health Service, Centers for Disease Control and Prevention, National Institute for Occupational Safety and Health: 49.

Earnest G.S., Beamer, B., Dunn, K., [2002]. An Evaluation of an Side Exhaust and Prototype and Production Emission Control Devices to Prevent Carbon Monoxide Poisonings from Generator Exhaust on Houseboats. Lake Mead, Nevada. USDHHS, PHS, CDC, NIOSH, Cincinnati, Ohio,_EPHB No. 171-29a.

Earnest, G.S., Hall, R.M., Dunn, K.H., Hammond, D., Valladares, R., [2003]. An Evaluation of Vertical Exhaust Stacks and Aged Production Emission Control Devices to Prevent Carbon Monoxide Poisonings from Houseboat Generator Exhaust. Lake Mead, Nevada. USDHHS, PHS, CDC, NIOSH, Cincinnati, Ohio, EPHB No. 171-32a.

Eastwood, P. (2000). Critical Topics in Exhaust Gas Aftertreatment. Hertfordshire, England, Research Studies Press Ltd.

Ehlers, J. J., J. B. McCammon, et al. (1996). NIOSH/CDPHE/CPSC/OSHA/EPA Alert: Preventing Carbon Monoxide Poisoning from Small Gasoline-Powered Engines and Tools, U.S. Department of Health and Human Services, Public Health Service, Centers for Disease Control and Prevention, National Institute for Occupational Safety and Health.

Envirolift (2001). Envirolift Product Literature. Charlotte, NC.

EPA (1991). Air Quality Criteria for Carbon Monoxide. Washington, DC, U.S. Environmental Protection Agency.

Forbes, W. H., F. Sargent, et al. (1945). The Rate of CO Uptake by Normal Man. A Journal of Physiology 143:594-608. 
Hall, R. M. (2000). Letter of December 18, 2000 from Ronald M. Hall, National Institute for Occupational Safety and Health, Centers for Disease Control and Prevention, Public Health Service, U.S. Department of Health and Human Services and to Rice C. Leach, Commissioner, Cabinet for Health Services, Department of Public Health, Commonwealth of Kentucky. Cincinnati, OH, NIOSH: December 18, 2000.

Hall, R. M. and J. B. McCammon (2000). Letter of November 21, 2000 from Ronald M. Hall and Jane B. McCammon, National Institute for Occupational Safety and Health, Centers for Disease Control and Prevention, Public Health Service, U.S. Department of Health and Human Services and to Joe Alston, Park Superintendent, Glen Canyon National Recreation Area, Page, Arizona. Cincinnati, OH, NIOSH: November 21, 2000.

Heck, R.M. and Farrauto, R.J. (1995). Catalytic Air Pollution Control: Commercial Technology. New York, New York, John Wiley \& Sons, Inc.

Heywood, J. B. (1988). Internal Combustion Engine Fundamentals. New York, New York, McGraw-Hill Inc.

Imanna Laboratory, Inc. (2001) Certification Test Report 15530-1 of Ignition Protection Tests on Environmental Carbon Monoxide Reduction System, ENV-JHW-1001, Rockledge, Florida.

Kales, S. N. (1993). Carbon Monoxide Intoxication." American Family Physician 48(6):11001104.

Kovein, R. J., G. S. Earnest, et al. (1998). CO Poisoning from Small Gasoline-Powered Engines: A Control Technology Solution, U.S. Department of Health and Human Services, Public Health Service, Centers for Disease Control and Prevention, National Institute for Occupational Safety and Health.

MariTech (2001). Conversation between Dr. G. Scott Earnest of EPHB, DART, NIOSH, and Keith Jackson, President of MariTech Industries, July 24, 2001. Anderson, California.

McCammon, J. B. and T. Radtke (2000). Letter of September 28, 2000 from J. McCammon, National Institute for Occupational Safety and Health, Centers for Disease Control and Prevention, Public Health Service, U.S. Department of Health and Human Services and T. Radtke, U.S. Department of the Interior, to Joe Alston, Park Superintendent, Glen Canyon National Recreation Area, Page, Arizona. Denver, CO, NIOSH.

McCammon, J. B., T. Radtke, et al. (2001). Letter of February 20, 2001, from J. McCammon, National Institute for Occupational Safety and Health, Centers for Disease Control and Prevention, Public Health Service, U.S. Department of Health and Human Services, T. Radtke, U.S. Department of the Interior, and Dr. Robert Baron Prehospital Medical Care, 
Glen Canyon National Recreation Area, to Joe Alston, Park Superintendent, Glen Canyon National Recreation Area, Page, Arizona. Denver, CO, NIOSH.

National Case Listing (2006). Boat-Related CO Poisonings on U.S. Waters: National Case Listing - Updated January 2006. The update was researched and prepared by members of the Double Angel Foundation CO Awareness Committee. Safety Management Information System (SMIS) U.S. Department of the Interior (DOI). http://safetynet.smis.doi.gov/ COhouseboats.htm accessed September 2006.

NIOSH (1972). Criteria for a Recommended Standard: Occupational Exposure to Carbon Monoxide. Cincinnati, $\mathrm{OH}$, National Institute for Occupational Safety and Health.

NIOSH (1977). Occupational Diseases: A Guide to their Recognition. Cincinnati, OH, National Institute for Occupational Safety and Health.

NIOSH (1979). A Guide to Work Relatedness of Disease. Cincinnati, OH, Department of Health Education and Welfare, Public Health Service, Centers for Disease Control, National Institute for Occupational Safety and Health.

NIOSH (2000). Pocket Guide to Chemical Hazards and Other Databases: Immediately Dangerous to Life and Health Concentrations, DHHS (NIOSH).

Plog, B. A. (1988). Fundamentals of Industrial Hygiene. Chicago, Illinois, National Safety Council.

Proctor, N. H., J. P. Hughes, et al. (1988). Chemical Hazards of the Workplace. Philadelphia, PA, J.P. Lippincott Co.

Simeone, L. F. (1990). A Simple Carburetor Model for Predicting Engine Air-Fuel Ratios and Carbon Monoxide Emissions as a Function of Inlet Conditions. Cambridge, Massachusetts, U.S. Department of Transportation, Research and Special Programs Administration: 11.

Westerbeke (2001). Conversation between Dr. G. Scott Earnest of EPHB, DART, NIOSH, and Carlton Bryant, Vice-President of Westerbeke Corporation, February 21, 2001. Avon, Massachusetts.

Westerbeke (2001). Unpublished Data: Engine exhaust emission test results. Taunton, MA: 2.

Zimmer, A.T., Earnest, G.S., Kurimo, R, [2005]. An Evaluation of Catalytic Emission Controls and Vertical Exhaust Stacks to Prevent Carbon Monoxide Poisonings from Houseboat Generator Exhaust. Lake Mead, Nevada. USDHHS, PHS, CDC, NIOSH, Cincinnati, Ohio, EPHB No. 17136 . 
Table I-CO Concentrations (ppm) on Fun Country Marine VIP XT (16' X59') Houseboat, 14-KW Safe-CO ${ }^{\text {TM }}$ Westerbeke Generator, Old catalyst, Stack-Exhaust Configuration $(11 / 16 / 2005)$

\begin{tabular}{|c|c|c|}
\hline $\begin{array}{l}\text { Sample Location } \\
\text { (Sample \#) }\end{array}$ & $\begin{array}{c}\text { Houseboat } \\
\text { Generator - No load }\end{array}$ & $\begin{array}{c}\text { Houseboat } \\
\text { Generator - 1/2 load }\end{array}$ \\
\hline $\begin{array}{l}\text { Upper Deck } \\
\text { Steering wheel } \\
\text { (Sample \#1) }\end{array}$ & $\begin{array}{c}\text { Mean }=1.4 \\
\text { Std. Dev. }=0.6 \\
\text { Peak }=3.0 \\
N=70\end{array}$ & $\begin{array}{c}\text { Mean }=3.0 \\
\text { Std. Dev. }=0.9 \\
\text { Peak }=5.0 \\
N=63\end{array}$ \\
\hline $\begin{array}{l}\text { Upper Deck } \\
\text { Wet bar } \\
\text { (Sample \#2) }\end{array}$ & $\begin{array}{c}\text { Mean }=2.4 \\
\text { Std. Dev. }=0.6 \\
\text { Peak }=4.0 \\
N=70\end{array}$ & $\begin{array}{c}\text { Mean }=1.9 \\
\text { Std. Dev. }=0.4 \\
\text { Peak }=3.0 \\
N=63\end{array}$ \\
\hline $\begin{array}{l}\text { Upper Stern Deck } \\
\text { Port Side (near stack) } \\
\text { (Sample \#3) }\end{array}$ & $\begin{array}{c}\text { Mean }=1.3 \\
\text { Std. Dev. }=0.6 \\
\text { Peak }=3.0 \\
N=70\end{array}$ & $\begin{array}{c}\text { Mean }=1.0 \\
\text { Std. Dev. }=0.4 \\
\text { Peak }=2.0 \\
N=63\end{array}$ \\
\hline $\begin{array}{l}\text { Upper Stern Deck } \\
\text { Port Side (on stair rail) } \\
\text { (Sample \#4) }\end{array}$ & $\begin{array}{c}\text { Mean }=1.9 \\
\text { Std. Dev. }=0.8 \\
\text { Peak }=5.0 \\
\mathrm{~N}=70\end{array}$ & $\begin{array}{c}\text { Mean }=0.8 \\
\text { Std. Dev. }=0.4 \\
\text { Peak }=1.0 \\
N=63\end{array}$ \\
\hline $\begin{array}{l}\text { Lower Stern Deck } \\
\text { Near Slide } \\
\text { (Sample \#5) }\end{array}$ & $\begin{array}{c}\text { Mean }=3.4 \\
\text { Std. Dev. }=0.7 \\
\text { Peak }=6.0 \\
N=70\end{array}$ & $\begin{array}{c}\text { Mean }=2.9 \\
\text { Std. Dev. }=0.4 \\
\text { Peak }=4.0 \\
N=63\end{array}$ \\
\hline $\begin{array}{l}\text { Lower Stern Deck } \\
\text { Port Side } \\
\text { (Sample \#6) }\end{array}$ & $\begin{array}{c}\text { Mean }=1.4 \\
\text { Std. Dev. }=0.5 \\
\text { Peak }=3.0 \\
\mathrm{~N}=70\end{array}$ & $\begin{array}{c}\text { Mean }=1.2 \\
\text { Std. Dev. }=05 \\
\text { Peak }=2.0 \\
N=63\end{array}$ \\
\hline $\begin{array}{l}\text { Lower Stern Deck } \\
\text { Starboard Side } \\
\text { (Sample \#7) }\end{array}$ & $\begin{array}{c}\text { Mean }=1.7 \\
\text { Std. Dev. }=1.1 \\
\text { Peak }=8.0 \\
N=70\end{array}$ & $\begin{array}{c}\text { Mean }=1.2 \\
\text { Std. Dev. }=0.4 \\
\text { Peak }=2.0 \\
N=63\end{array}$ \\
\hline $\begin{array}{l}\text { Lower Stern Deck } \\
\text { Port Side } \\
\text { (Sample \#8) }\end{array}$ & $\begin{array}{c}\text { Mean }=2.0 \\
\text { Std. Dev. }=0.5 \\
\text { Peak }=3.0 \\
N=70\end{array}$ & $\begin{array}{c}\text { Mean }=1.8 \\
\text { Std. Dev. }=0.4 \\
\text { Peak }=2.0 \\
N=63\end{array}$ \\
\hline $\begin{array}{l}\text { Lower Stern Deck } \\
\text { Back of Slide } \\
\text { (Sample \#9) }\end{array}$ & $\begin{array}{c}\text { Mean }=1.7 \\
\text { Std. Dev. }=0.7 \\
\text { Peak }=4.0 \\
N=70\end{array}$ & $\begin{array}{c}\text { Mean }=1.4 \\
\text { Std. Dev. }=0.5 \\
\text { Peak }=2.0 \\
N=63\end{array}$ \\
\hline
\end{tabular}

$\mathrm{N}=$ number of data points 
Table II--CO Concentrations (ppm) on Fun Country Marine VIP XT (16' X 59') Houseboat, 14-KW Safe-CO ${ }^{\text {TM }}$ Westerbeke Generator, Old catalyst, Side-Exhaust Configuration (11/16/2005)

\begin{tabular}{|c|c|c|}
\hline $\begin{array}{l}\text { Sample Location } \\
\text { (Sample \#) }\end{array}$ & $\begin{array}{c}\text { Houseboat } \\
\text { Generator - No load }\end{array}$ & $\begin{array}{c}\text { Houseboat } \\
\text { Generator - 1/2 load }\end{array}$ \\
\hline $\begin{array}{l}\text { Upper Deck } \\
\text { Steering wheel } \\
\text { (Sample \#1) }\end{array}$ & $\begin{array}{c}\text { Mean }=3.4 \\
\text { Std. Dev. }=1.2 \\
\text { Peak }=5.0 \\
N=56\end{array}$ & $\begin{array}{c}\text { Mean }=1.7 \\
\text { Std. Dev. }=0.5 \\
\text { Peak }=3.0 \\
N=67\end{array}$ \\
\hline $\begin{array}{l}\text { Upper Deck } \\
\text { Wet bar } \\
\text { (Sample \#2) }\end{array}$ & $\begin{array}{c}\text { Mean }=1.8 \\
\text { Std. Dev. }=0.4 \\
\text { Peak }=2.0 \\
N=56\end{array}$ & $\begin{array}{c}\text { Mean }=1.7 \\
\text { Std. Dev. }=0.5 \\
\text { Peak }=3.0 \\
N=67\end{array}$ \\
\hline $\begin{array}{l}\text { Upper Stern Deck } \\
\text { Port Side (near stack) } \\
\text { (Sample \#3) }\end{array}$ & $\begin{array}{c}\text { Mean }=1.2 \\
\text { Std. Dev. }=0.5 \\
\text { Peak }=2.0 \\
\mathrm{~N}=56\end{array}$ & $\begin{array}{c}\text { Mean }=0.9 \\
\text { Std. Dev. }=0.5 \\
\text { Peak }=2.0 \\
N=67\end{array}$ \\
\hline $\begin{array}{l}\text { Upper Stern Deck } \\
\text { Port Side (on stair rail) } \\
\text { (Sample \#4) }\end{array}$ & $\begin{array}{c}\text { Mean }=0.8 \\
\text { Std. Dev. }=0.4 \\
\text { Peak }=1.0 \\
N=56\end{array}$ & $\begin{array}{c}\text { Mean }=1.0 \\
\text { Std. Dev. }=0.3 \\
\text { Peak }=2.0 \\
N=67\end{array}$ \\
\hline $\begin{array}{l}\text { Lower Stern Deck } \\
\text { Near Slide } \\
\text { (Sample \#5) }\end{array}$ & $\begin{array}{c}\text { Mean }=2.9 \\
\text { Std. Dev. }=0.5 \\
\text { Peak }=5.0 \\
N=56\end{array}$ & $\begin{array}{c}\text { Mean }=2.9 \\
\text { Std. Dev. }=0.5 \\
\text { Peak }=4.0 \\
N=67\end{array}$ \\
\hline $\begin{array}{l}\text { Lower Stern Deck } \\
\text { Port Side } \\
\text { (Sample \#6) }\end{array}$ & $\begin{array}{c}\text { Mean }=1.3 \\
\text { Std. Dev. }=0.5 \\
\text { Peak }=2.0 \\
N=56\end{array}$ & $\begin{array}{c}\text { Mean }=1.6 \\
\text { Std. Dev. }=0.5 \\
\text { Peak }=3.0 \\
N=67\end{array}$ \\
\hline $\begin{array}{l}\text { Lower Stern Deck } \\
\text { Starboard Side } \\
\text { (Sample \#7) }\end{array}$ & $\begin{array}{c}\text { Mean }=1.1 \\
\text { Std. Dev. }=0.3 \\
\text { Peak }=2.0 \\
N=56\end{array}$ & $\begin{array}{c}\text { Mean }=1.1 \\
\text { Std. Dev. }=0.4 \\
\text { Peak }=2.0 \\
N=67\end{array}$ \\
\hline $\begin{array}{l}\text { Lower Stern Deck } \\
\text { Port Side } \\
\text { (Sample \#8) }\end{array}$ & $\begin{array}{c}\text { Mean }=1.6 \\
\text { Std. Dev. }=0.5 \\
\text { Peak }=2.0 \\
\mathrm{~N}=56\end{array}$ & $\begin{array}{c}\text { Mean }=1.4 \\
\text { Std. Dev. }=0.5 \\
\text { Peak }=3.0 \\
N=67\end{array}$ \\
\hline $\begin{array}{l}\text { Lower Stern Deck } \\
\text { Back of Slide } \\
\text { (Sample \#9) }\end{array}$ & $\begin{array}{c}\text { Mean }=1.3 \\
\text { Std. Dev. }=0.5 \\
\text { Peak }=1.0 \\
N=56\end{array}$ & $\begin{array}{c}\text { Mean }=1.4 \\
\text { Std. Dev. }=0.5 \\
\text { Peak }=3.0 \\
N=67\end{array}$ \\
\hline
\end{tabular}

$\mathrm{N}=$ number of data points 
(11/16/2005)

\begin{tabular}{|c|c|c|}
\hline $\begin{array}{l}\text { Sample Location } \\
\text { (Sample \#) }\end{array}$ & $\begin{array}{c}\text { Houseboat } \\
\text { Generator - No load }\end{array}$ & $\begin{array}{c}\text { Houseboat } \\
\text { Generator - 1/2 load }\end{array}$ \\
\hline $\begin{array}{l}\text { Upper Deck } \\
\text { Steering wheel } \\
\text { (Sample \#1) }\end{array}$ & $\begin{array}{c}\text { Mean }=1.6 \\
\text { Std. Dev. }=0.5 \\
\text { Peak }=3.0 \\
N=80\end{array}$ & $\begin{array}{c}\text { Mean }=0.6 \\
\text { Std. Dev. }=0.7 \\
\text { Peak }=2.0 \\
N=32\end{array}$ \\
\hline $\begin{array}{l}\text { Upper Deck } \\
\text { Wet bar } \\
\text { (Sample \#2) }\end{array}$ & $\begin{array}{c}\text { Mean }=1.6 \\
\text { Std Dev. }=0.5 \\
\text { Peak }=3.0 \\
N=80\end{array}$ & $\begin{array}{c}\text { Mean }=0.8 \\
\text { Std. Dev. }=0.6 \\
\text { Peak }=2.0 \\
N=56\end{array}$ \\
\hline $\begin{array}{l}\text { Upper Stern Deck } \\
\text { Port Side (near stack) } \\
\text { (Sample \#3) }\end{array}$ & $\begin{array}{c}\text { Mean }=1.1 \\
\text { Std. Dev. }=0.5 \\
\text { Peak }=2.0 \\
N=80\end{array}$ & $\begin{array}{c}\text { Mean }=1.1 \\
\text { Std. Dev. }=0.4 \\
\text { Peak }=2.0 \\
N=56\end{array}$ \\
\hline $\begin{array}{l}\text { Upper Stern Deck } \\
\text { Port Side (on stair rail) } \\
\text { (Sample \#4) }\end{array}$ & $\begin{array}{c}\text { Mean }=0.9 \\
\text { Std Dev. }=0.3 \\
\text { Peak }=1.0 \\
N=80\end{array}$ & $\begin{array}{c}\text { Mean }=1.0 \\
\text { Std. Dev. }=0.4 \\
\text { Peak }=2.0 \\
N=56\end{array}$ \\
\hline $\begin{array}{l}\text { Lower Stern Deck } \\
\text { Near Slide } \\
\text { (Sample \#5) }\end{array}$ & $\begin{array}{c}\text { Mean }=1.4 \\
\text { Std. Dev. }=2.0 \\
\text { Peak }=17.0 \\
N=80\end{array}$ & $\begin{array}{c}\text { Mean }=1.1 \\
\text { Std. Dev. }=0.5 \\
\text { Peak }=3.0 \\
N=56\end{array}$ \\
\hline $\begin{array}{l}\text { Lower Stern Deck } \\
\text { Port Side } \\
\text { (Sample \#6) }\end{array}$ & $\begin{array}{c}\text { Mean }=2.6 \\
\text { Std. Dev. }=2.2 \\
\text { Peak }=15.0 \\
N=80\end{array}$ & $\begin{array}{c}\text { Mean }=3.1 \\
\text { Std. Dev. }=0.9 \\
\text { Peak }=6.0 \\
\mathrm{~N}=56\end{array}$ \\
\hline $\begin{array}{l}\text { Lower Stern Deck } \\
\text { Starboard Side } \\
\text { (Sample \#7) }\end{array}$ & $\begin{array}{c}\text { Mean }=0.6 \\
\text { Std. Dev. }=0.5 \\
\text { Peak }=1.0 \\
\mathrm{~N}=80\end{array}$ & $\begin{array}{c}\text { Mean }=0.4 \\
\text { Std. Dev. }=0.5 \\
\text { Peak }=2.0 \\
N=56\end{array}$ \\
\hline $\begin{array}{l}\text { Lower Stern Deck } \\
\text { Port Side } \\
\text { (Sample \#8) }\end{array}$ & $\begin{array}{c}\text { Mean }=1.1 \\
\text { Std. } \text { Dev. }=0.4 \\
\text { Peak }=2.0 \\
\mathrm{~N}=80\end{array}$ & $\begin{array}{c}\text { Mean }=1.1 \\
\text { Std. Dev. }=0.4 \\
\text { Peak }=2.0 \\
N=56\end{array}$ \\
\hline $\begin{array}{l}\text { Lower Stern Deck } \\
\text { Back of Slide } \\
\text { (Sample \#9) }\end{array}$ & $\begin{array}{c}\text { Mean }=1.3 \\
\text { Std. Dev. }=0.5 \\
\text { Peak }=3.0 \\
N=80\end{array}$ & $\begin{array}{c}\text { Mean }=1.2 \\
\text { Std. Dev. }=0.6 \\
\text { Peak }=4.0 \\
N=56\end{array}$ \\
\hline
\end{tabular}

$\mathrm{N}=$ number of data points 
Table IV--CO Concentrations (ppm) on Fun Country Marine VIP XT (16' X 59') Houseboat, 14-KW Safe-CO ${ }^{\mathrm{TM}}$ Westerbeke Generator, New catalyst, Stack-Exhaust $(11 / 16 / 2005)$

\begin{tabular}{|c|c|c|}
\hline $\begin{array}{l}\text { Sample Location } \\
\text { (Sample \#) }\end{array}$ & $\begin{array}{c}\text { Houseboat } \\
\text { Generator - No load }\end{array}$ & $\begin{array}{c}\text { Houseboat } \\
\text { Generator }-1 / 2 \text { load }\end{array}$ \\
\hline $\begin{array}{l}\text { Upper Deck } \\
\text { Steering wheel } \\
\text { (Sample \#1) }\end{array}$ & $\begin{array}{c}\text { Mean }=0.5 \\
\text { Std. Dev. }=1.0 \\
\text { Peak }=6.0 \\
N=64\end{array}$ & $\begin{array}{c}\text { Mean }=1.7 \\
\text { Std. Dev. }=1.6 \\
\text { Peak }=11.0 \\
N=42\end{array}$ \\
\hline $\begin{array}{l}\text { Upper Deck } \\
\text { Wet bar } \\
\text { (Sample \#2) }\end{array}$ & $\begin{array}{c}\text { Mean }=1.0 \\
\text { Std. Dev. }=1.0 \\
\text { Peak }=5.0 \\
N=64\end{array}$ & $\begin{array}{c}\text { Mean }=1.1 \\
\text { Std. Dev. }=1.3 \\
\text { Peak }=6.0 \\
N=42\end{array}$ \\
\hline $\begin{array}{l}\text { Upper Stern Deck } \\
\text { Port Side (near stack) } \\
\text { (Sample \#3) }\end{array}$ & $\begin{array}{c}\text { Mean }=1.3 \\
\text { Std. Dev. }=0.8 \\
\text { Peak }=4.0 \\
N=64\end{array}$ & $\begin{array}{c}\text { Mean }=1.3 \\
\text { Std. Dev. }=0.6 \\
\text { Peak }=4.0 \\
N=42\end{array}$ \\
\hline $\begin{array}{l}\text { Upper Stern Deck } \\
\text { Port Side (on stair rail) } \\
\text { (Sample \#4) }\end{array}$ & $\begin{array}{c}\text { Mean }=1.2 \\
\text { Std. Dev. }=06 \\
\text { Peak }=40 \\
N=64\end{array}$ & $\begin{array}{c}\text { Mean }=1.1 \\
\text { Std. Dev. }=0.4 \\
\text { Peak }=2.0 \\
\mathrm{~N}=42\end{array}$ \\
\hline $\begin{array}{l}\text { Lower Stern Deck } \\
\text { Near Slide } \\
\text { (Sample \#5) }\end{array}$ & $\begin{array}{c}\text { Mean }=1.6 \\
\text { Std. Dev. }=0.6 \\
\text { Peak }=40 \\
N=64\end{array}$ & $\begin{array}{c}\text { Mean }=1.6 \\
\text { Std. Dev. }=0.5 \\
\text { Peak }=3.0 \\
\mathrm{~N}=42\end{array}$ \\
\hline $\begin{array}{l}\text { Lower Stern Deck } \\
\text { Port Side } \\
\text { (Sample \#6) }\end{array}$ & $\begin{array}{c}\text { Mean }=3.2 \\
\text { Std. Dev. }=0.7 \\
\text { Peak }=60 \\
N=64\end{array}$ & $\begin{array}{c}\text { Mean }=5.0 \\
\text { Std. Dev. }=0.3 \\
\text { Peak }=6.0 \\
\mathrm{~N}=42\end{array}$ \\
\hline $\begin{array}{l}\text { Lower Stern Deck } \\
\text { Starboard Side } \\
\text { (Sample \#7) }\end{array}$ & $\begin{array}{c}\text { Mean }=0.6 \\
\text { Std. Dev. }=0.7 \\
\text { Peak }=3.0 \\
N=64\end{array}$ & $\begin{array}{c}\text { Mean }=0.4 \\
\text { Std. Dev. }=0.5 \\
\text { Peak }=1.0 \\
N=42\end{array}$ \\
\hline $\begin{array}{l}\text { Lower Stern Deck } \\
\text { Port Side } \\
\text { (Sample \#8) }\end{array}$ & $\begin{array}{c}\text { Mean }=1.1 \\
\text { Std. Dev. }=0.6 \\
\text { Peak }=2.0 \\
N=64\end{array}$ & $\begin{array}{c}\text { Mean }=1.0 \\
\text { Std. Dev. }=0.4 \\
\text { Peak }=2.0 \\
\mathrm{~N}=42\end{array}$ \\
\hline $\begin{array}{l}\text { Lower Stern Deck } \\
\text { Back of Slide } \\
\text { (Sample \#9) }\end{array}$ & $\begin{array}{c}\text { Mean }=1.3 \\
\text { Std. Dev. }=0.6 \\
\text { Peak }=3.0 \\
\mathrm{~N}=64\end{array}$ & $\begin{array}{c}\text { Mean }=1.3 \\
\text { Std. Dev. }=0.4 \\
\text { Peak }=2.0 \\
N=42\end{array}$ \\
\hline
\end{tabular}

$\mathrm{N}=$ number of data points 
Table V-CO Concentrations (ppm) on Fun Country Marine (14' X 59') Houseboat, 12.5KW Westerbeke Generator Retrofitted with a Zenith Electronic Fuel Injection Kit and Stack-Exhaust (11/16/2005)

\begin{tabular}{|c|c|c|}
\hline $\begin{array}{l}\text { Sample Location } \\
\text { (Sample \#) }\end{array}$ & $\begin{array}{c}\text { Houseboat } \\
\text { Generator - No load }\end{array}$ & $\begin{array}{c}\text { Houseboat } \\
\text { Generator }-1 / 2 \text { load }\end{array}$ \\
\hline $\begin{array}{l}\text { Upper Deck } \\
\text { Steering wheel } \\
\text { (Sample \#1) }\end{array}$ & $\begin{array}{c}\text { Mean }=0.4 \\
\text { Std. Dev. }=0.5 \\
\text { Peak }=1.0 \\
\mathrm{~N}=43\end{array}$ & $\begin{array}{c}\text { Mean }=3.0 \\
\text { Std. Dev. }=3.6 \\
\text { Peak }=11.0 \\
N=41\end{array}$ \\
\hline $\begin{array}{l}\text { Upper Deck } \\
\text { Wet bar } \\
\text { (Sample \#2) }\end{array}$ & $\begin{array}{c}\text { Mean }=0.9 \\
\text { Std. Dev. }=0.5 \\
\text { Peak }=2.0 \\
N=43\end{array}$ & $\begin{array}{c}\text { Mean }=2.6 \\
\text { Std. Dev. }=2.2 \\
\text { Peak }=8.0 \\
\mathrm{~N}=39\end{array}$ \\
\hline $\begin{array}{l}\text { Upper Stern Deck } \\
\text { Port Side (near stack) } \\
\text { (Sample \#3) }\end{array}$ & $\begin{array}{c}\text { Mean }=0.9 \\
\text { Std. Dev. }=0.4 \\
\text { Peak }=2.0 \\
N=43\end{array}$ & $\begin{array}{c}\text { Mean }=2.9 \\
\text { Std. Dev. }=2.5 \\
\text { Peak }=10.0 \\
N=41\end{array}$ \\
\hline $\begin{array}{l}\text { Upper Stern Deck } \\
\text { Port Side (on stair rail) } \\
\text { (Sample \#4) }\end{array}$ & $\begin{array}{c}\text { Mean }=0.9 \\
\text { Std. Dev. }=0.3 \\
\text { Peak }=1.0 \\
N=43\end{array}$ & $\begin{array}{c}\text { Mean }=2.9 \\
\text { Std. Dev. }=1.9 \\
\text { Peak }=8.0 \\
N=41\end{array}$ \\
\hline $\begin{array}{l}\text { Lower Stern Deck } \\
\text { Near Slide } \\
\text { (Sample \#5) }\end{array}$ & $\begin{array}{c}\text { Mean }=1.5 \\
\text { Std Dev. }=0.5 \\
\text { Peak }=2.0 \\
N=43\end{array}$ & $\begin{array}{c}\text { Mean }=3.7 \\
\text { Std. Dev. }=3.3 \\
\text { Peak }=14.0 \\
\mathrm{~N}=41\end{array}$ \\
\hline $\begin{array}{l}\text { Lower Stern Deck } \\
\text { Port Side } \\
\text { (Sample \#6) }\end{array}$ & $\begin{array}{c}\text { Mean }=2.3 \\
\text { Std. Dev. }=0.5 \\
\text { Peak }=3.0 \\
\mathrm{~N}=43\end{array}$ & $\begin{array}{c}\text { Mean }=3.6 \\
\text { Std. Dev. }=3.0 \\
\text { Peak }=12.0 \\
N=41\end{array}$ \\
\hline $\begin{array}{l}\text { Lower Stern Deck } \\
\text { Starboard Side } \\
\text { (Sample \#7) }\end{array}$ & $\begin{array}{c}\text { Mean }=0.5 \\
\text { Std. Dev. }=0.5 \\
\text { Peak }=1.0 \\
\mathrm{~N}=43\end{array}$ & $\begin{array}{c}\text { Mean }=2.3 \\
\text { Std. Dev. }=2.4 \\
\text { Peak }=10.0 \\
N=41\end{array}$ \\
\hline $\begin{array}{l}\text { Lower Stern Deck } \\
\text { Port Side } \\
\text { (Sample \#8) }\end{array}$ & $\begin{array}{c}\text { Mean }=0.9 \\
\text { Std. Dev. }=0.4 \\
\text { Peak }=2.0 \\
N=43\end{array}$ & $\begin{array}{c}\text { Mean }=2.6 \\
\text { Std. Dev. }=2.7 \\
\text { Peak }=11.0 \\
N=41\end{array}$ \\
\hline $\begin{array}{l}\text { Lower Stern Deck } \\
\text { Back of Slide } \\
\text { (Sample \#9) }\end{array}$ & $\begin{array}{c}\text { Mean }=1.0 \\
\text { Std. Dev. }=0.2 \\
\text { Peak }=2.0 \\
\mathrm{~N}=43\end{array}$ & $\begin{array}{c}\text { Mean }=2.8 \\
\text { Std. Dev. }=2.0 \\
\text { Peak }=9.0 \\
N=41\end{array}$ \\
\hline
\end{tabular}

$\mathrm{N}=$ number of data points 
Table VI-CO Concentrations (ppm) on Fun Country Marine VIP XT (16' X 70') Houseboat, 20-KW Safe-CO ${ }^{\mathrm{TM}}$ Westerbeke Generator, Old catalyst, Stack-Exhaust Configuration (11/17/2005)

\begin{tabular}{|c|c|c|}
\hline $\begin{array}{l}\text { Sample Location } \\
\text { (Sample \#) }\end{array}$ & $\begin{array}{c}\text { Houseboat } \\
\text { Generator - No load }\end{array}$ & $\begin{array}{c}\text { Houseboat } \\
\text { Generator - 1/2 load }\end{array}$ \\
\hline $\begin{array}{l}\text { Upper Deck } \\
\text { Steering wheel } \\
\text { (Sample \#1) }\end{array}$ & $\begin{array}{c}\text { Mean }=1.5 \\
\text { Std. Dev. }=0.7 \\
\text { Peak }=4.0 \\
N=96\end{array}$ & $\begin{array}{c}\text { Mean }=2.2 \\
\text { Std. Dev. }=0.6 \\
\text { Peak }=3.0 \\
\mathrm{~N}=42\end{array}$ \\
\hline $\begin{array}{l}\text { Upper Deck } \\
\text { Wet bar } \\
\text { (Sample \#2) }\end{array}$ & $\begin{array}{c}\text { Mean }=1.9 \\
\text { Std. Dev. }=0.5 \\
\text { Peak }=3.0 \\
\mathrm{~N}=96\end{array}$ & $\begin{array}{c}\text { Mean }=1.6 \\
\text { Std. Dev. }=0.5 \\
\text { Peak }=2.0 \\
\mathrm{~N}=42\end{array}$ \\
\hline $\begin{array}{l}\text { Upper Stern Deck } \\
\text { Port Side (near stack) } \\
\text { (Sample \#3) }\end{array}$ & $\begin{array}{c}\text { Mean }=0.9 \\
\text { Std. Dev. }=0.5 \\
\text { Peak }=4.0 \\
\mathrm{~N}=96\end{array}$ & $\begin{array}{c}\text { Mean }=0.8 \\
\text { Std. Dev. }=0.5 \\
\text { Peak }=2.0 \\
\mathrm{~N}=42\end{array}$ \\
\hline $\begin{array}{l}\text { Upper Stern Deck } \\
\text { Port Side (on stair rail) } \\
\text { (Sample \#4) }\end{array}$ & $\begin{array}{c}\text { Mean }=0.6 \\
\text { Std. Dev. }=0.5 \\
\text { Peak }=2.0 \\
\mathrm{~N}=96\end{array}$ & $\begin{array}{c}\text { Mean }=0.2 \\
\text { Std. Dev. }=0.4 \\
\text { Peak }=1.0 \\
\mathrm{~N}=42\end{array}$ \\
\hline $\begin{array}{l}\text { Lower Stern Deck } \\
\text { Near Slide } \\
\text { (Sample \#5) }\end{array}$ & $\begin{array}{c}\text { Mean }=2.3 \\
\text { Std. Dev. }=0.6 \\
\text { Peak }=4.0 \\
\mathrm{~N}=96\end{array}$ & $\begin{array}{c}\text { Mean }=2.2 \\
\text { Std. Dev. }=0.4 \\
\text { Peak }=3.0 \\
\mathrm{~N}=42\end{array}$ \\
\hline $\begin{array}{l}\text { Lower Stern Deck } \\
\text { Port Side } \\
\text { (Sample \#6) }\end{array}$ & $\begin{array}{c}\text { Mean }=0.9 \\
\text { Std. Dev. }=0.3 \\
\text { Peak }=2.0 \\
\mathrm{~N}=96\end{array}$ & $\begin{array}{c}\text { Mean }=1.1 \\
\text { Std. Dev. }=0.3 \\
\text { Peak }=2.0 \\
N=42\end{array}$ \\
\hline $\begin{array}{l}\text { Lower Stern Deck } \\
\text { Starboard Side } \\
\text { (Sample \#7) }\end{array}$ & $\begin{array}{c}\text { Mean }=1.0 \\
\text { Std. Dev. }=0.4 \\
\text { Peak }=2.0 \\
\mathrm{~N}=96\end{array}$ & $\begin{array}{c}\text { Mean }=0.9 \\
\text { Std. Dev. }=0.5 \\
\text { Peak }=2.0 \\
\mathrm{~N}=42\end{array}$ \\
\hline $\begin{array}{l}\text { Lower Stern Deck } \\
\text { Port Side } \\
\text { (Sample \#8) }\end{array}$ & $\begin{array}{c}\text { Mean }=1.0 \\
\text { Std. Dev. }=0.5 \\
\text { Peak }=2.0 \\
N=96\end{array}$ & $\begin{array}{c}\text { Mean }=0.7 \\
\text { Std. Dev. }=0.5 \\
\text { Peak }=1.0 \\
N=42\end{array}$ \\
\hline $\begin{array}{l}\text { Lower Stern Deck } \\
\text { Back of Slide } \\
\text { (Sample \#9) }\end{array}$ & $\begin{array}{c}\text { Mean }=1.8 \\
\text { Std. Dev. }=0.4 \\
\text { Peak }=2.0 \\
\mathrm{~N}=96\end{array}$ & $\begin{array}{c}\text { Mean }=1.6 \\
\text { Std. Dev. }=0.5 \\
\text { Peak }=2.0 \\
N=42\end{array}$ \\
\hline
\end{tabular}

$\mathrm{N}=$ number of data points 
Table VII--CO Concentrations (ppm) on Fun Country Marine VIP XT (16' X 70') Houseboat, 20-KW Safe-CO ${ }^{\mathrm{TM}}$ Westerbeke Generator, New catalyst, Stack-Exhaust Configuration (11/17/2005)

\begin{tabular}{|c|c|c|}
\hline $\begin{array}{l}\text { Sample Location } \\
\text { (Sample \#) }\end{array}$ & $\begin{array}{c}\text { Houseboat } \\
\text { Generator - No load }\end{array}$ & $\begin{array}{c}\text { Houseboat } \\
\text { Generator - 1/2 load }\end{array}$ \\
\hline $\begin{array}{l}\text { Upper Deck } \\
\text { Steering wheel } \\
\text { (Sample \#1) }\end{array}$ & $\begin{array}{c}\text { Mean }=3.9 \\
\text { Std. Dev. }=1.0 \\
\text { Peak }=6.0 \\
N=52\end{array}$ & $\begin{array}{c}\text { Mean }=2.6 \\
\text { Std. Dev. }=0.7 \\
\text { Peak }=5.0 \\
N=55\end{array}$ \\
\hline $\begin{array}{l}\text { Upper Deck } \\
\text { Wet bar } \\
\text { (Sample \#2) }\end{array}$ & $\begin{array}{c}\text { Mean }=1.2 \\
\text { Std. Dev. }=0.4 \\
\text { Peak }=2.0 \\
\mathrm{~N}=52\end{array}$ & $\begin{array}{c}\text { Mean }=1.1 \\
\text { Std. Dev. }=0.5 \\
\text { Peak }=3.0 \\
N=55\end{array}$ \\
\hline $\begin{array}{l}\text { Upper Stern Deck } \\
\text { Port Side (near stack) } \\
\text { (Sample \#3) }\end{array}$ & $\begin{array}{c}\text { Mean }=0.9 \\
\text { Std. Dev. }=0.5 \\
\text { Peak }=2.0 \\
N=52\end{array}$ & $\begin{array}{c}\text { Mean }=0.8 \\
\text { Std. Dev. }=0.6 \\
\text { Peak }=3.0 \\
N=55\end{array}$ \\
\hline $\begin{array}{l}\text { Upper Stern Deck } \\
\text { Port Side (on stair rail) } \\
\text { (Sample \#4) }\end{array}$ & $\begin{array}{c}\text { Mean }=0.3 \\
\text { Std. Dev. }=0.5 \\
\text { Peak }=2.0 \\
\mathrm{~N}=52\end{array}$ & $\begin{array}{c}\text { Mean }=0.3 \\
\text { Std. Dev. }=0.5 \\
\text { Peak }=1.0 \\
N=54\end{array}$ \\
\hline $\begin{array}{l}\text { Lower Stern Deck } \\
\text { Near Slide } \\
\text { (Sample \#5) }\end{array}$ & $\begin{array}{c}\text { Mean }=1.9 \\
\text { Std. Dev. }=0.8 \\
\text { Peak }=3.0 \\
\mathrm{~N}=52\end{array}$ & $\begin{array}{c}\text { Mean }=1.8 \\
\text { Std. Dev. }=0.9 \\
\text { Peak }=4.0 \\
N=55\end{array}$ \\
\hline $\begin{array}{l}\text { Lower Stern Deck } \\
\text { Port Side } \\
\text { (Sample \#6) }\end{array}$ & $\begin{array}{c}\text { Mean }=1.3 \\
\text { Std. Dev. }=0.5 \\
\text { Peak }=2.0 \\
\mathrm{~N}=52\end{array}$ & $\begin{array}{c}\text { Mean }=1.6 \\
\text { Std. Dev. }=0.6 \\
\text { Peak }=3.0 \\
N=55\end{array}$ \\
\hline $\begin{array}{l}\text { Lower Stern Deck } \\
\text { Starboard Side } \\
\text { (Sample \#7) }\end{array}$ & $\begin{array}{c}\text { Mean }=0.3 \\
\text { Std. Dev. }=0.4 \\
\text { Peak }=1.0 \\
N=52\end{array}$ & $\begin{array}{c}\text { Mean }=0.2 \\
\text { Std. Dev. }=0.4 \\
\text { Peak }=1.0 \\
N=55\end{array}$ \\
\hline $\begin{array}{l}\text { Lower Stern Deck } \\
\text { Port Side } \\
\text { (Sample \#8) }\end{array}$ & $\begin{array}{c}\text { Mean }=0.4 \\
\text { Std. Dev. }=0.5 \\
\text { Peak }=1.0 \\
\mathrm{~N}=52\end{array}$ & $\begin{array}{c}\text { Mean }=0.3 \\
\text { Std. Dev. }=0.5 \\
\text { Peak }=1.0 \\
\mathrm{~N}=55\end{array}$ \\
\hline $\begin{array}{l}\text { Lower Stern Deck } \\
\text { Back of Slide } \\
\text { (Sample \#9) }\end{array}$ & $\begin{array}{c}\text { Mean }=1.0 \\
\text { Std. Dev. }=0.5 \\
\text { Peak }=2.0 \\
N=52\end{array}$ & $\begin{array}{c}\text { Mean }=1.1 \\
\text { Std. Dev. }=0.4 \\
\text { Peak }=2.0 \\
N=55\end{array}$ \\
\hline
\end{tabular}

$\mathrm{N}=$ number of data points 
Table VIII -- CO Detector Tube Results (ppm) taken adjacent (Side Exhaust Configuration, $\sim 24$ " above the exhaust) or within the Exhaust Plumes (Top Exhaust Configuration)

\begin{tabular}{|c|c|c|c|}
\hline $\begin{array}{l}\text { Boat, Condition } \\
\text { (Test Date) }\end{array}$ & Sample & Condition & $\begin{array}{l}\text { Sample } \\
\text { Result }\end{array}$ \\
\hline $\begin{array}{l}\text { CO Concentrations (ppm) on Fun Country Marine VIP } \\
\text { XT (16' X 59') Houseboat, 14-KW Safe-CO } \\
\text { Westerbeke Generator }\end{array}$ & $\begin{array}{l}1 \\
2 \\
3 \\
4 \\
5 \\
6 \\
7 \\
8 \\
9 \\
10\end{array}$ & $\begin{array}{l}3 \\
3 \\
4 \\
4 \\
1 \\
2 \\
1 \\
2 \\
3 \\
4\end{array}$ & $\begin{array}{l}19 \\
\mathrm{ND} \\
30 \\
2 \\
\mathrm{ND} \\
10 \\
\mathrm{ND} \\
15 \\
2 \\
25\end{array}$ \\
\hline $\begin{array}{l}\text { CO Concentrations (ppm) on Fun Country Marine (14' } \\
\text { X 59') Houseboat, 12.5-KW Westerbeke Generator } \\
\text { Retrofitted with a Zenith Electronic Fuel Injection Kit }\end{array}$ & $\begin{array}{l}11 \\
12 \\
13 \\
14 \\
15\end{array}$ & $\begin{array}{l}3 \\
3 \\
3 \\
4 \\
4\end{array}$ & $\begin{array}{l}3,000 \\
600 \\
900 \\
3,000+ \\
40,000 \mathrm{CS}\end{array}$ \\
\hline $\begin{array}{l}\text { Fun Country Marine VIP XT }\left(16^{\prime} \text { X } 70^{\prime}\right) \text { Houseboat, } \\
20-\mathrm{KW} \text { Safe-CO }{ }^{\mathrm{TM}} \text { Westerbeke Generator }\end{array}$ & $\begin{array}{l}16 \\
17 \\
18 \\
19 \\
20 \\
21 \\
22 \\
23 \\
24\end{array}$ & $\begin{array}{l}3 \\
3 \\
3 \\
4 \\
4 \\
3 \\
3 \\
4 \\
4\end{array}$ & $\begin{array}{l}70,000 \mathrm{CS} \\
5,000 \mathrm{CS} \\
20 \\
1,000 \\
10 \\
\mathrm{ND} \\
24 \\
8 \\
12\end{array}$ \\
\hline
\end{tabular}

$\mathrm{ND}=$ none detected $\mathrm{CS}=$ cold start

Condition 1: side exhaust, no generator load

Condition 2: side exhaust, generator load

Condition 3: stack, no generator load

Condition 4: stack, generator load 
Table IX -- CO Evacuated Container Results (ppm) taken adjacent (Side Exhaust Configuration, 24" above the exhaust) or within the Exhaust Plumes (Top Exhaust Configuration)

\begin{tabular}{|c|c|c|c|}
\hline $\begin{array}{l}\text { Boat, Condition } \\
\text { (Test Date) }\end{array}$ & Sample & Condition/ Comment & $\begin{array}{l}\text { Sample } \\
\text { Result }\end{array}$ \\
\hline $\begin{array}{l}\text { CO Concentrations (ppm) on Fun Country } \\
\text { Marine VIP XT (16' X 59') Houseboat, 14- } \\
\text { KW Safe-CO }{ }^{\text {TM }} \text { Westerbeke Generator }\end{array}$ & $\begin{array}{l}1 \\
2 \\
3 \\
4 \\
5 \\
6 \\
7 \\
8 \\
9 \\
10\end{array}$ & $\begin{array}{l}3, \text { Cold start } \\
3 \\
4 \\
4 \\
1 \\
2 \\
1, \text { Cold start } \\
2 \\
3 \\
4\end{array}$ & $\begin{array}{l}81,001 \\
1 \\
77 \\
2 \\
1 \\
27 \\
11,170 \\
3 \\
39 \\
6\end{array}$ \\
\hline $\begin{array}{l}\text { CO Concentrations (ppm) on Fun Country } \\
\text { Marine (14' X 59') Houseboat, 12.5-KW } \\
\text { Westerbeke Generator Retrofitted with a } \\
\text { Zenith Electronic Fuel Injection Kit }\end{array}$ & $\begin{array}{l}11 \\
12 \\
13 \\
14 \\
15\end{array}$ & $\begin{array}{l}3 \\
3 \\
4 \\
4 \\
4\end{array}$ & $\begin{array}{l}742 \\
518 \\
772 \\
8 \\
13224\end{array}$ \\
\hline $\begin{array}{l}\left.\text { Fun Country Marine VIP XT ( } 16^{\prime} \text { X } 70^{\prime}\right) \\
\text { Houseboat, } 20-\mathrm{KW} \text { Safe-CO }{ }^{\mathrm{TM}} \text { Westerbeke } \\
\text { Generator }\end{array}$ & $\begin{array}{l}16 \\
17 \\
18 \\
19 \\
20 \\
21 \\
22 \\
23 \\
24\end{array}$ & $\begin{array}{l}3 \text {, Cold start } \\
3 \\
3 \\
4 \\
4 \\
3 \text {, Cold start } \\
3 \\
4 \\
4\end{array}$ & $\begin{array}{l}119,261 \\
11 \\
30 \\
29 \\
326 \\
52059 \\
19 \\
163 \\
11\end{array}$ \\
\hline
\end{tabular}

$\mathrm{ND}=$ none detected;

Condition 1: side exhaust, no generator load

Condition 2: side exhaust, generator load

Condition 3: stack, no generator load

Condition 4: stack, generator load 


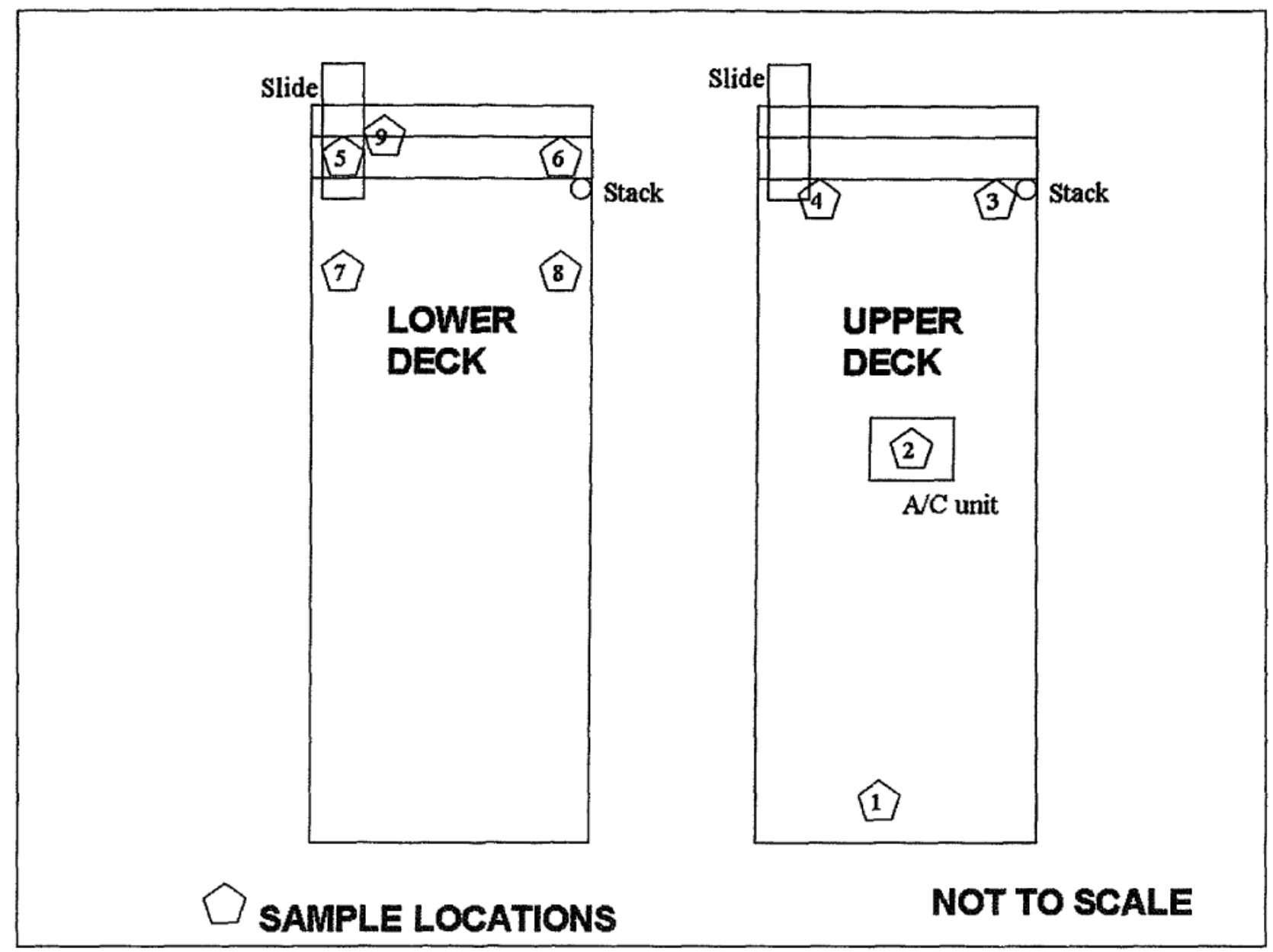

Figure 1. Diagram of evaluated houseboats and air sampling locations. 


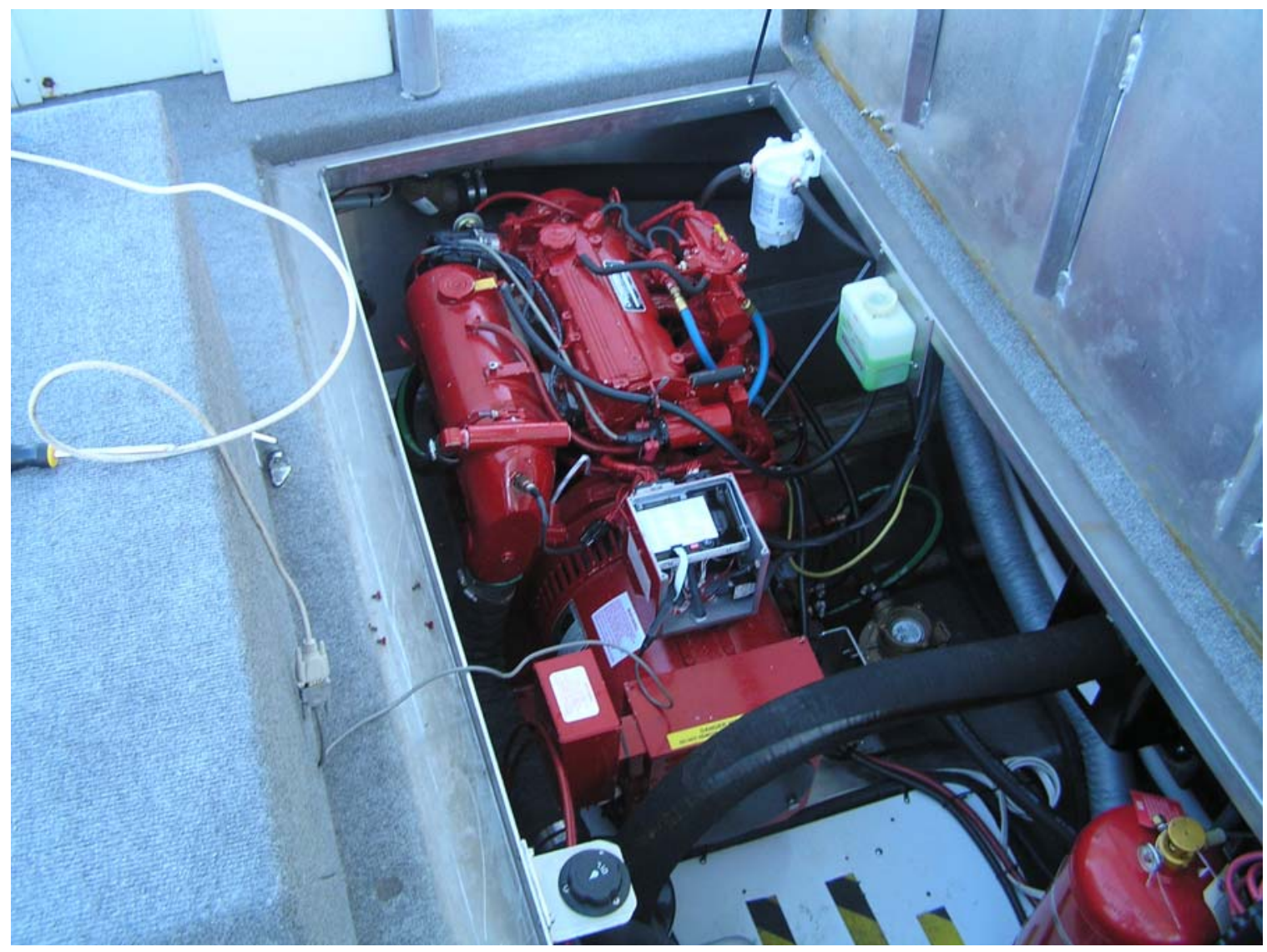

Figure 2. Photo of the Westerbeke Safe CO generator with catalyst. 


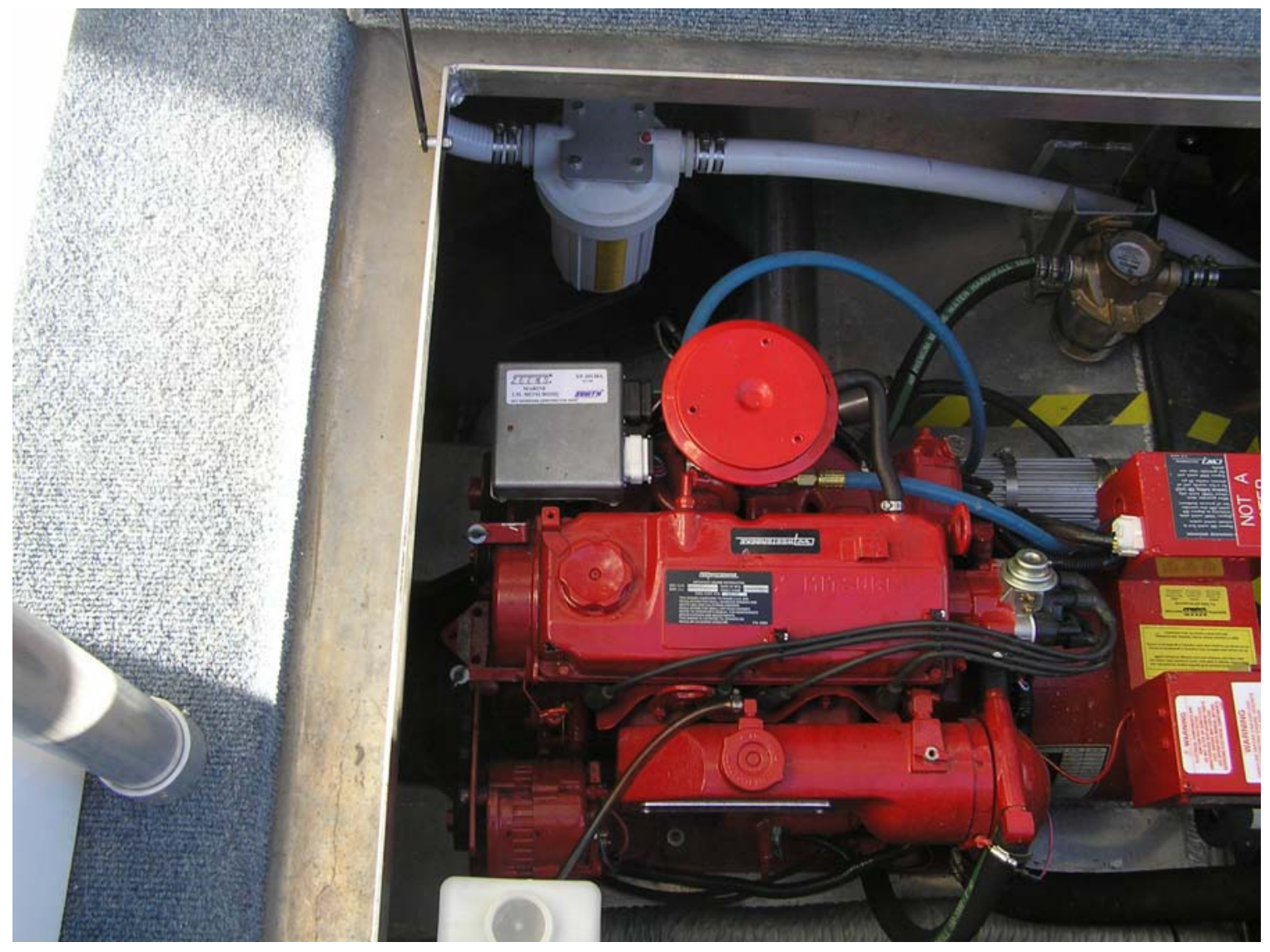

Figure 3. Photo of Westerbeke Generator with Zenith Electronic Fuel Injection kit. 